\title{
Fra altings oprindelse - til livets opståen
}

Af Henning Haack ${ }^{1}$, Uffe Gråe Jørgensen², Anja Andersen ${ }^{2}$, Martin Bizzarro og Vagn Fabritius Buchwald ${ }^{1}$ - tidligere DTU. 1) Geologisk Museum, Statens Naturhistoriske Museum ${ }^{2)}$ NBI (Niels Bohr Instituttet), ${ }^{3)}$ Geologisk Institut; alle Københavns Universitet

Hvor kommer vi fra, hvordan er Jorden og resten af Solsystemet blevet til? Hvornår skabtes alting, og hvordan er det gået til, at vi i dag befinder os på en planet kredsende omkring en stjerne, vi har valgt at kalde Solen?

I løbet af forbløffende kort tid har mennesket udviklet sig til at være så intelligent, at vi faktisk langt hen af vejen kan svare på disse helt fundamentale spørgsmål. I denne artikel vil vi prøve at give det naturvidenskabelige bud på skabelsesberetningen. Det er en beretning, der hele tiden ændrer sig i takt med, at nye opdagelser og teorier sætter os i stand til at grave dybere ned i vores forhistorie. Større teleskoper sætter os både i stand til at se længere ud i universet og finde nye objekter i Solsystemets fjerneste og mest uforandrede afkroge. Stadigt forbedrede analysemetoder sætter os samtidig i stand til at aflæse den information, der har været gemt i meteoritter, der daterer sig helt tilbage til Solsystemets oprindelse. Gang på gang lykkes det af løfte endnu en flig af det slør, der dækker over vores fælles oprindelse.

\section{Geologi og astronomi er beslægtede}

GeologiskNyt beskæftiger sig ellers normalt ikke med astronomiske emner som Universets oprindelse, supernova-eksplosioner og stjerners udvikling. Men disse emner er i virkeligheden nært beslægtede med geovidenskaberne. Alle grundstoffer på Jorden og i resten af Solsystemet er et resultat af Universets udvikling. Datering af bjergarter, der er en af grundpillerne i geovidenskaberne, baserer sig på henfaldet af radioaktive stoffer. De fleste af disse stoffer skabtes i stjerner og supernova-eksplosioner, i tiden inden Solsystemet blev skabt. Isotopsammensætning af meteoritter og jordiske bjergarter kan omvendt fortælle astronomer noget om stjerners udvikling.

Hvis du vil vide mere om emnet kan du

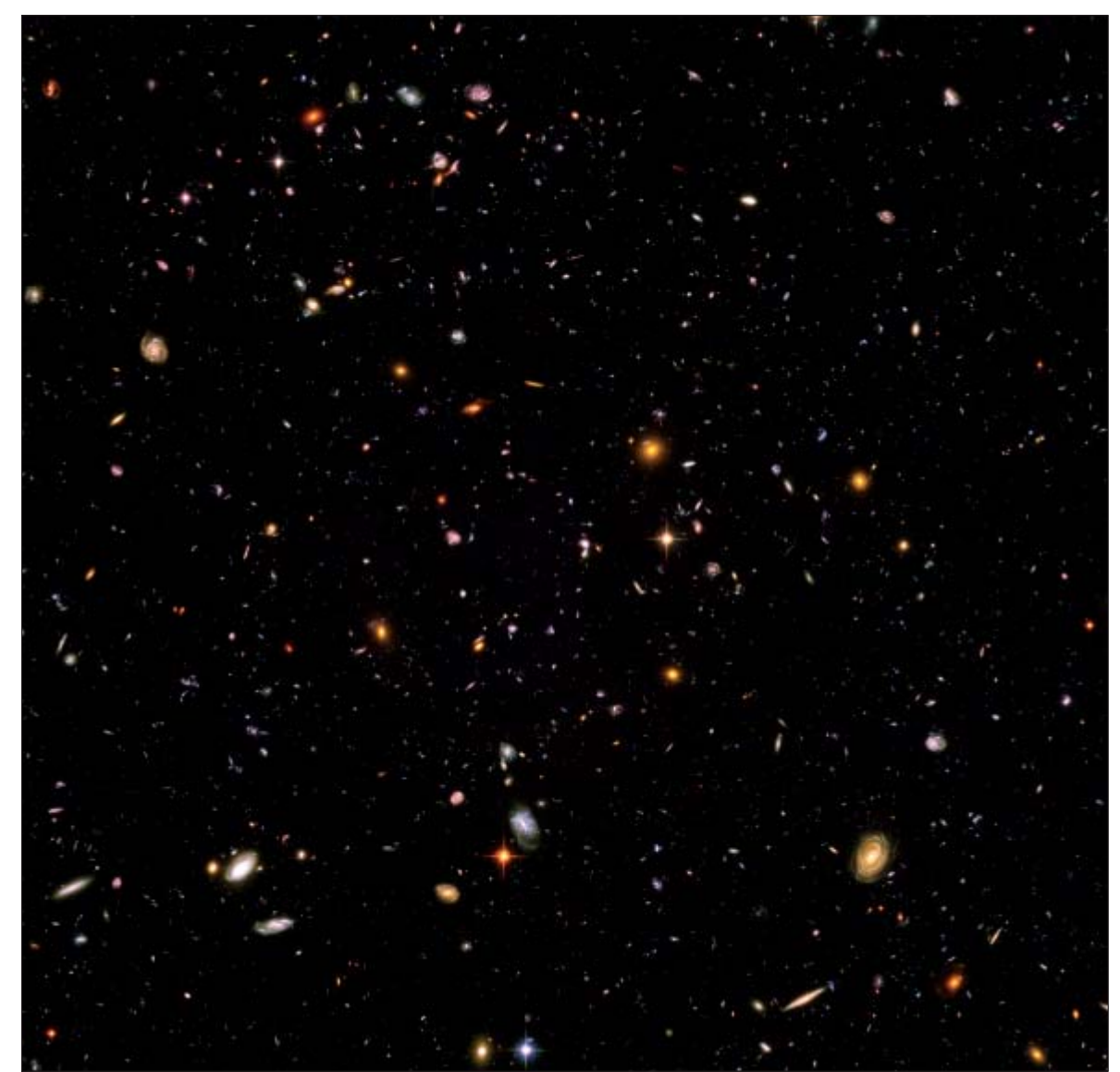

Et af Hubble Space-teleskopets mest spektakulcre billeder fremkom ved at rette teleskopet mod et tilsyneladende mørkt og tomt område på himlen i 1 million sekunder. Ved at eksponere så lange kunne man se ekstremt lyssvage galakser. Fra de svageste modtog teleskopet ca. 1 foton per sekund. I alt viser billedet 10.000 galakser - hvoraf kun ganske få kan ses fra Jorden. De fjerneste var kun mellem 400 og 800 millioner år gamle, da de udsendte det lys, vi ser nu. Hubble Space Ultra Deep Field. (® NASA, ESA)

besøge Geologisk Museums nye permanente Udstilling: Solsystemet - Fra altings oprindelse til livets opståen. Her vil du også kunne se meteoritter fra Månen og Mars. I artiklen her vil vi fortælle om meteoritter fra asteroider og den historie, de kan fortælle os om vores Solsystems oprindelse.

For 14 mia. år siden fandtes der ingenting! Det er ikke bare Jorden og solsystemet, skovene og søerne, stjernerne og skyerne, der endnu ikke var til. Der var ikke noget stof, ikke noget rum og ingen tid. Det er meget svært at forestille sig, og videnskaben har kun nogle meget vage ideer om, hvordan alting kan være blevet skabt ud af ingenting.

Hvad, vi ved, er, at for ca. 13,6 milliarder år siden var alt det, der I dag findes i universet, samlet i et uhyre lille område. Måske så lille et område som et knappenålshoved. Der var intet udenom. Af dette ufatteligt kompakte og varme område blev hele universet til.

Man kan med rette forestille sig det meget tidlige univers som en suppe af energi. Der var ingen molekyler og atomer. Ingen grundstoffer. Kun uhyre varmt. Hastigt udvidedes og afkøledes universet. I dag er universet ufattelig stort, men til gengæld er rummet blevet umådelig koldt. Der er stort set $-270{ }^{\circ} \mathrm{C}$ i alle retninger, men bitte små variationer i temperaturen afslører nogle af de vigtigste detaljer om, hvordan universet må have set ud, lige efter det var skabt. 


\section{Grundstofferne opstår}

Et minut efter universet blev til, havde det udvidet og afkølet sig så meget, at atomkerne-partikler begyndte at klumpe ud af "suppen". Det var protoner, neutroner og elektroner. Alle grundstofferne er opbygget af protoner, neutroner og elektroner - og intet andet. Så efter et minut var ingredienserne til alle grundstofferne blevet til, men der skulle endnu gå milliarder af år, inden de blev til de mange grundstoffer, vi kender omkring os - byggestenene i hele den fysiske verden, der omgiver os.

Observationer og eksperimenter har vist, at universets ursuppe kun dannede brint og helium, og de tre sjældne grundstoffer lithium, beryllium, og bor. Det skyldes bl.a., at neutronen er ustabil. Når den bevæger sig frit i rummet - altså ikke sidder inde i et atom - omdanner en typisk neutron sig til en proton i løbet af ca. 10 minutter. Der var altså kun af størrelsesordenen 10 minutter til rådighed i universets begyndelse til at danne grundstoffer. Derefter var der ikke flere neutroner til rådighed til nye grundstoffer. Resten af grundstofferne er dannet gennem milliarder af år, dybt inde i stjerner.

\section{Stjerner som grundstoffabrikker}

Stjernerne er gigantiske, kontrollerede fusionskraftværker, der skaber energi til deres lys ved at "forbrænde" (altså fusionere) lette grundstoffer til stadigt tungere grundstoffer. Det er den samme energikilde, som driver en brintbombe eller måske engang et fusi-
Stjerner producerer energi ved at fusionere lette grundstoffer til tungere grundstoffer. Hvis stjernen er stor nok, vil tryk og temperatur i dens indre vœre højt nok til, at der kan dannes jern. (Grafik: Anne Haastrup Hansen, Statens Naturhistoriske Museum)

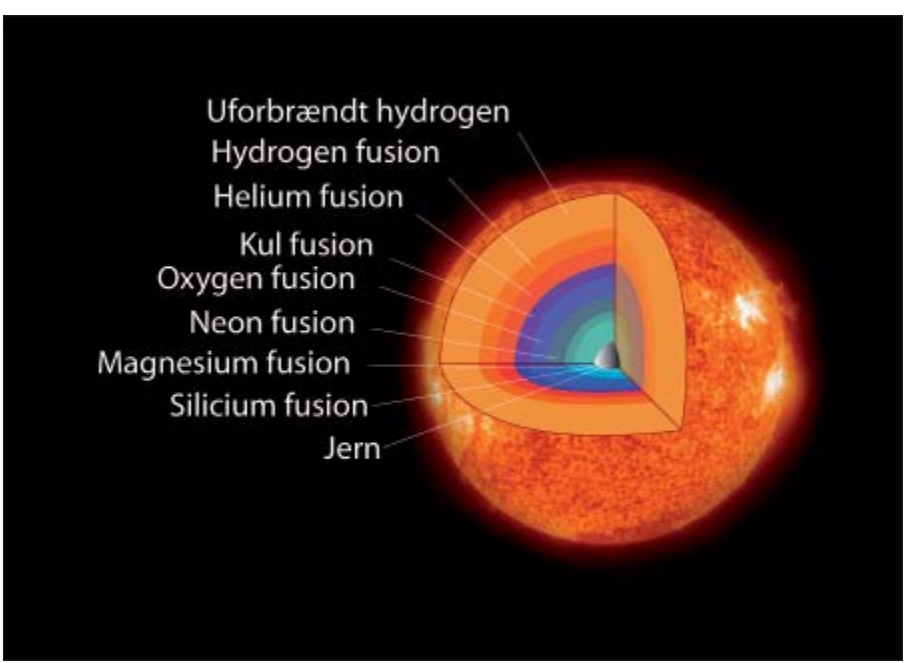

onskraftværk. I størstedelen af stjernernes liv får de deres energi ved at omdanne brint til helium. Herved får vi altså stadig mere helium i universet og stadig mindre brint - men endnu ingen kul og jern mv.

Mod slutningen af stjernernes liv er de blevet så varme indeni, at helium kan omdannes videre til kulstof og kvælstof, og for nogles vedkommende videre til ilt, neon, aluminium, osv. op til og med jern (figuren øverst til højre). Når stoffet er blevet til jern, kan man ikke vinde mere energi ved yderligere fusioner. Hvis stjernen er stor nok, vil stadigt større områder i dens indre blive til jern. Til sidst vil der være skabt en så mægtig boble af jerndamp (egentlig "jern-plas-

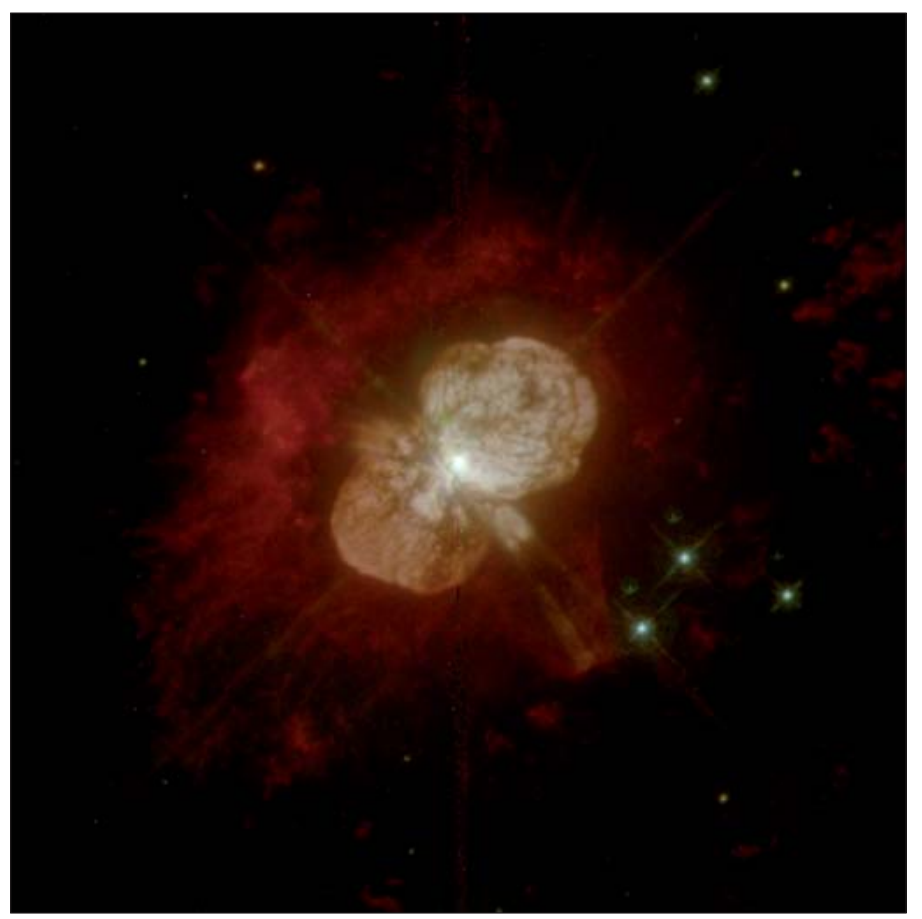

En af meelkevejens tungeste stjerner er Eta Carinae. Den er mindst 100 gange tungere end Solen og udsender 4 mio. gange så meget lys. Fordi stjernen er så stor, producerer den ekstremt meget energi og blceser derfor med mellemrum store mcengder gas ud. Senest i april 1843 hvor den kortvarigt var himlens næestkraftigste stjerne. Billedet viser, hvordan gassen fra dette udbrud delvist skjuler stjernen. De mindste detaljer i billedet er på størrelse med vores solsystem. Eta Carinae forventes at gennemgå en supernovaeksplosion inden for de nceste 100.000 år. (C NASA)

ma") i stjernens indre, at jern-atomkernerne ikke længere kan modstå vægten af sig selv. På det tidspunkt sker der noget højst bemærkelsesværdigt. Jern-atomkernerne bryder sammen under deres egen vægt og bliver igen til neutroner. Neutronerne styrter sammen mod stjernens centrum og danner til sidst en lille neutronklump - en neutronstjerne - på kun 10 kilometers størrelse. Hver kubikcentimeter af dens stof vejer en milliard tons. Dannelsen af neutronstjernen udløser så meget energi, at hele resten af stjernen blæses ud i rummet. Det er det, man ser som en supernovaeksplosion (se figuren til venstre).

\section{Eksploderende stjerner}

I supernovaeksplosionen blæses det stof ud, som stjernen har skabt gennem millioner af år. Astronomerne estimerer, at stort set alt det ilt, fluor, neon, natrium, magnesium, aluminium, silicium, fosfor, svovl, chlor, argon, kalium, calcium, scandium, titan, vanadium, chrom, mangan, jern, cobalt, og nikkel, der findes i naturen er "affaldsproduktet" fra de atomkerneprocesser, der har fået de store stjerner til at lyse gennem deres liv.

Under selve supernovaeksplosionen vil store mængder nydannede neutroner blæse gennem stjernens gasser. Herved vil specielt det jern, der findes i stjernen blive ændret til meget tunge grundstoffer. Der vindes ikke energi ved disse processer. De forbruger noget af den energi, eksplosionen indeholder. Fx dannes naturens tungeste grundstof, uran, ved at jern optager de energirige neutroner fra eksplosionen. Når den radioaktive uran på Jorden henfalder over milliarder af år og opvarmer Jordens skorpe, kan man med rette sige, at det er rester fra supernovaeksplosionens enorme energireserver, der holder jordskorpen varm. Også grundstoffer som guld, platin, osmium, selen, europium, og xenon dannes på denne måde. De er alle kommet til os fra en eksploderende stjerne.

Det er kun de allerstørste stjerner, der bliver til supernovaer. Stjerner, der fødes med mindre end 8 gange Solens masse, formår kun at forbrænde deres grundstoffer 
frem til kulstof og kvælstof. Herefter stopper kerneforbrændingerne. Der bliver aldrig varmt nok i deres indre til, at kulstoffet kan forbrændes videre til ilt, neon, magnesium, osv. til jern. Til gengæld kommer det meste - måske alt - kulstof og kvælstof i naturen fra forbrændingerne i de "små" stjerner altså dem der ligesom vores egen Sol aldrig vil blive til supernovaer.

Gennem en besynderlig række af "minieksplosioner" i slutningen af de relativt små stjerners liv, skabes der også strømme af nydannede neutroner. Neutronerne her er forskellige i deres energi fra neutronerne $\mathrm{i}$ supernovaeksplosionen. Derfor danner de andre tunge grundstoffer end supernovaeksplosionerne gør. Omkring 2/3 af alle grundstoffer tungere end jern dannes her - bl.a. barium, bly, og strontium.

De små stjerner eksploderer aldrig, men de puster sig voldsomt op i slutningen af deres liv. Solen vil om ca. 7 milliarder år blive lige så stor som Jordens nuværende bane om Solen. På det tidspunkt er Solen blevet til det, man kalder en rød kæmpestjerne. En million milliarder tons stof vil blæses ud af Solen hvert sekund i denne fase af dens liv (figuren til højre). Disse stoffer vil være beriget på kulstof, kvælstof, bly og mange andre stoffer, der er dannet i Solens indre gennem dens liv. Måske vil varmen fra disse enorme gasmasser fordampe Jorden på det tidspunkt, og vores jordiske rester vil blæse med solstoffet ud i det interstellare rum, hvor det engang vil blive til nye stjerner og planeter, i naturens evige opbygning af stadigt mere komplekse former for materie.

\section{En stjerne fødes}

Noget af den gas, stjernerne slynger ud, når de ender deres liv, samles i enorme skyer, hvorfra der kan dannes nye generationer af stjerner. Når en del af gasskyen når en kritisk størrelse, masse eller massetæthed (densitet), begynder den at falde sammen under sit eget tyngdefelt. Som gasskyen skrumper ind vil den, ligesom en roterende skøjteløber, der trækker armene ind til krop-

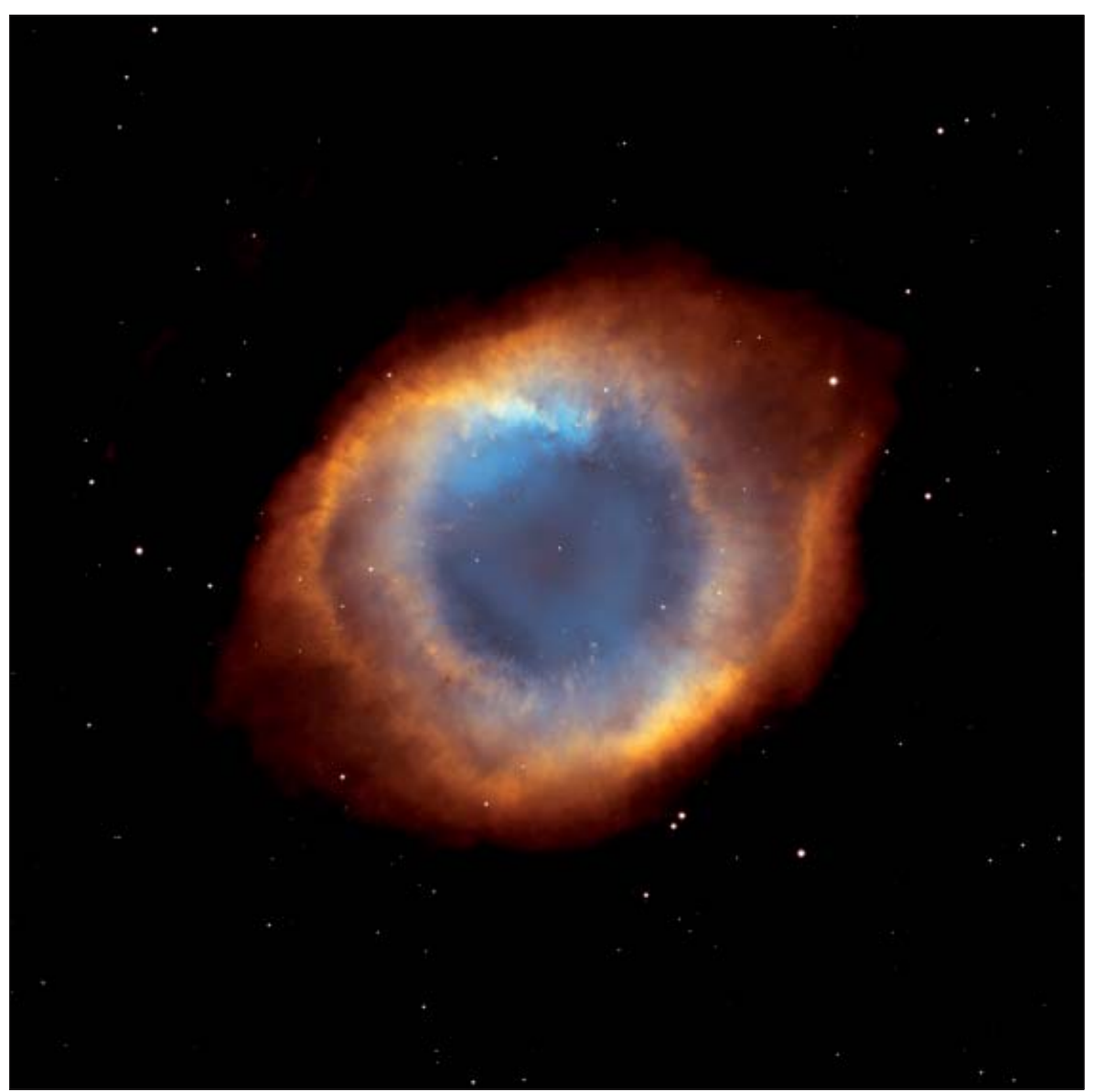

Helix Nebula. Billedet viser en døende stjerne i stil med vores egen sol. Lige inden stjernen brcender ud, afstøder den sine yderste lag, der ses som en lysende gassky omkring stjernen. (C) NASA, ESA)

pen, rotere hurtigere og hurtigere. Denne rotationsbevægelse får skyen til at flade ud og begynde at tage form som en skive - også kaldet en protoplanetarisk skive. Sådanne protoplanetariske skiver kan på nuværende tidspunkt observeres i Ørnetågen, Eagle Nebula (foto øverst til højre på næste side), og kan muligvis give os et indblik $i$, hvordan vores eget solsystem kan have set ud for ca. 4,56 mia. år siden. Langt det meste materiale i Solsystemet endte i Solen, mens planeterne dannedes udfra det tilbage- værende materiale i den protoplanetariske skive. Ved at klumpe sig sammen, når de stødte sammen, blev dét, der startede som støvpartikler, til større og større objekter som asteroider og planeter (foto øverst til venstre på næste side).

\section{Kondritter og det første faste stof}

I området mellem Mars og Jupiter dannedes der aldrig en egentlig planet. Årsagen er formentlig, at Jupiter med sit enorme tyngdefelt sørgede for at slynge langt det meste 


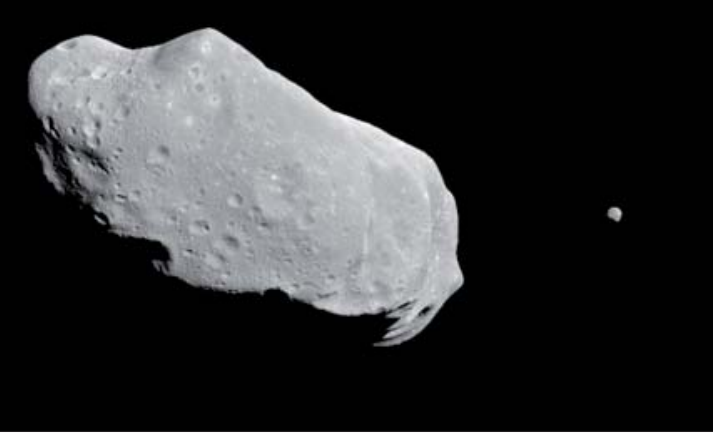

Den $50 \mathrm{~km}$ lange asteroide Ida og dens $1 \mathrm{~km}$ lille måne Dactyl, fotograferet fra rumsonden Galileo, under turen gennem asteroidebceltet på dens vej til Jupiter i august 1993. (C) NASA)

materiale væk, inden der kunne opbygges en planet. Selvom det er lidt ærgerligt, at vi er gået glip af endnu en planet på nattehimlen, kan vi glæde os over, at vi til gengæld har fået bevaret noget af det allerførste faste stof, der dannedes i solsystemet. Dele af den oprindelige støvskive klumpede sig sammen til asteroider, der aldrig har haft nogen væsentlig geologisk udvikling. Meteoritter fra sådanne asteroider indeholder derfor primitivt støv og partikler, der daterer sig helt tilbage til Solsystemets oprindelse. Denne type meteoritter kaldes kondritter, fordi de indeholder masser af let genkendelige kugler kaldet kondruler.

Der findes mange forskellige typer kondritter med vidt forskellige egenskaber. Der er stor forskel på størrelsen af de kondruler og andre partikler, kondritterne indeholder, men også deres kemiske sammensætning varierer meget. Da de alle er prøver fra det tidlige solsystem, viser det os, at der var

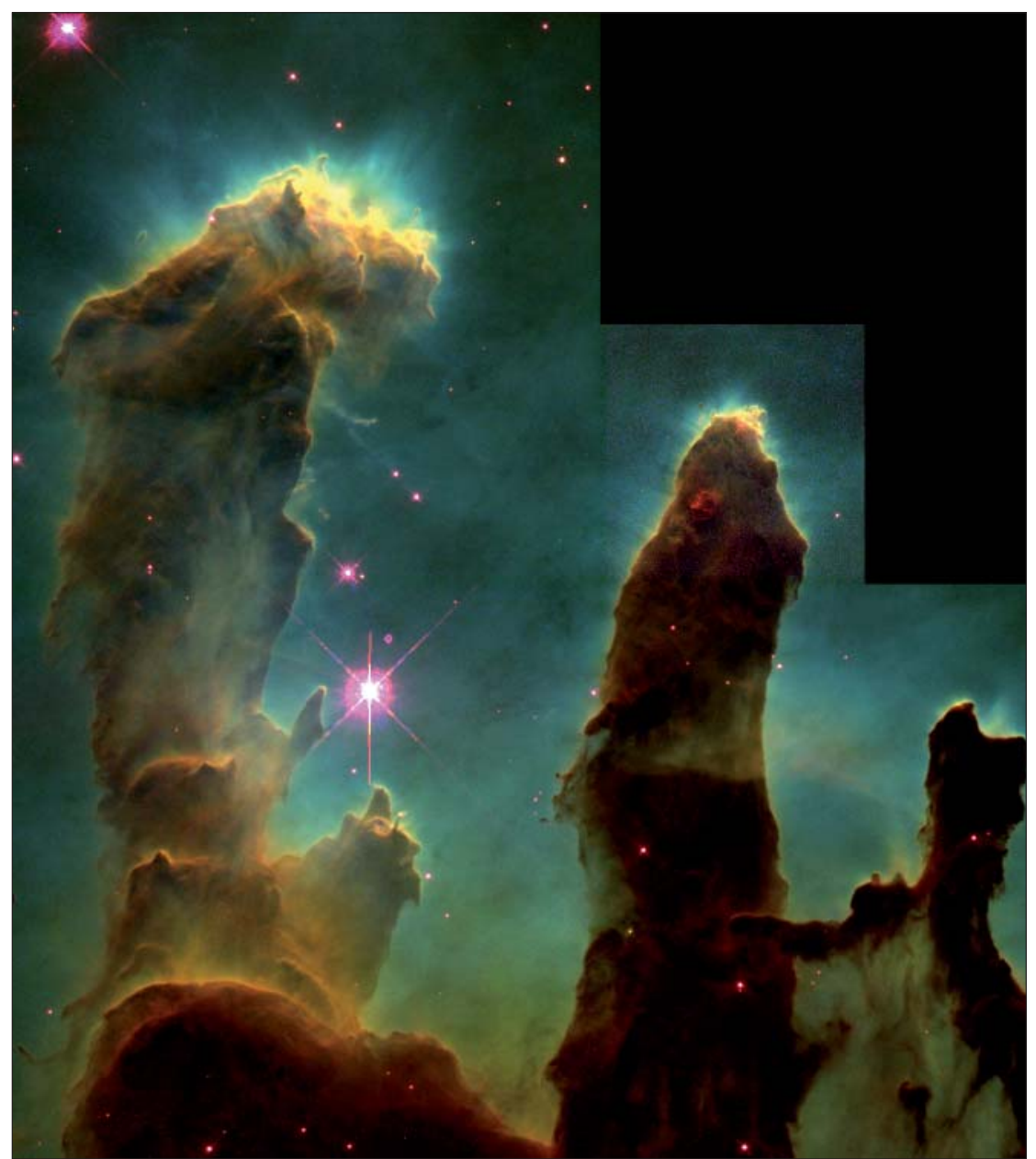

Ørnetågen er et af de bedst studerende områder i Mcelkevejen, hvor der i øjeblikket dannes stjerner. Man kan forestille sig, at Solsystemet blev dannet sammen med mange andre stjerner $i$ en lignende gassky. (@ ESA, NASA)

store variationer i det støv, der kredsede omkring Solen og senere blandt andet blev brugt til at opbygge planeterne. Specielt de såkaldte kulkondritter er interessante, da det materiale, de indeholder, er særdeles velbevaret (de to figurer nederst).
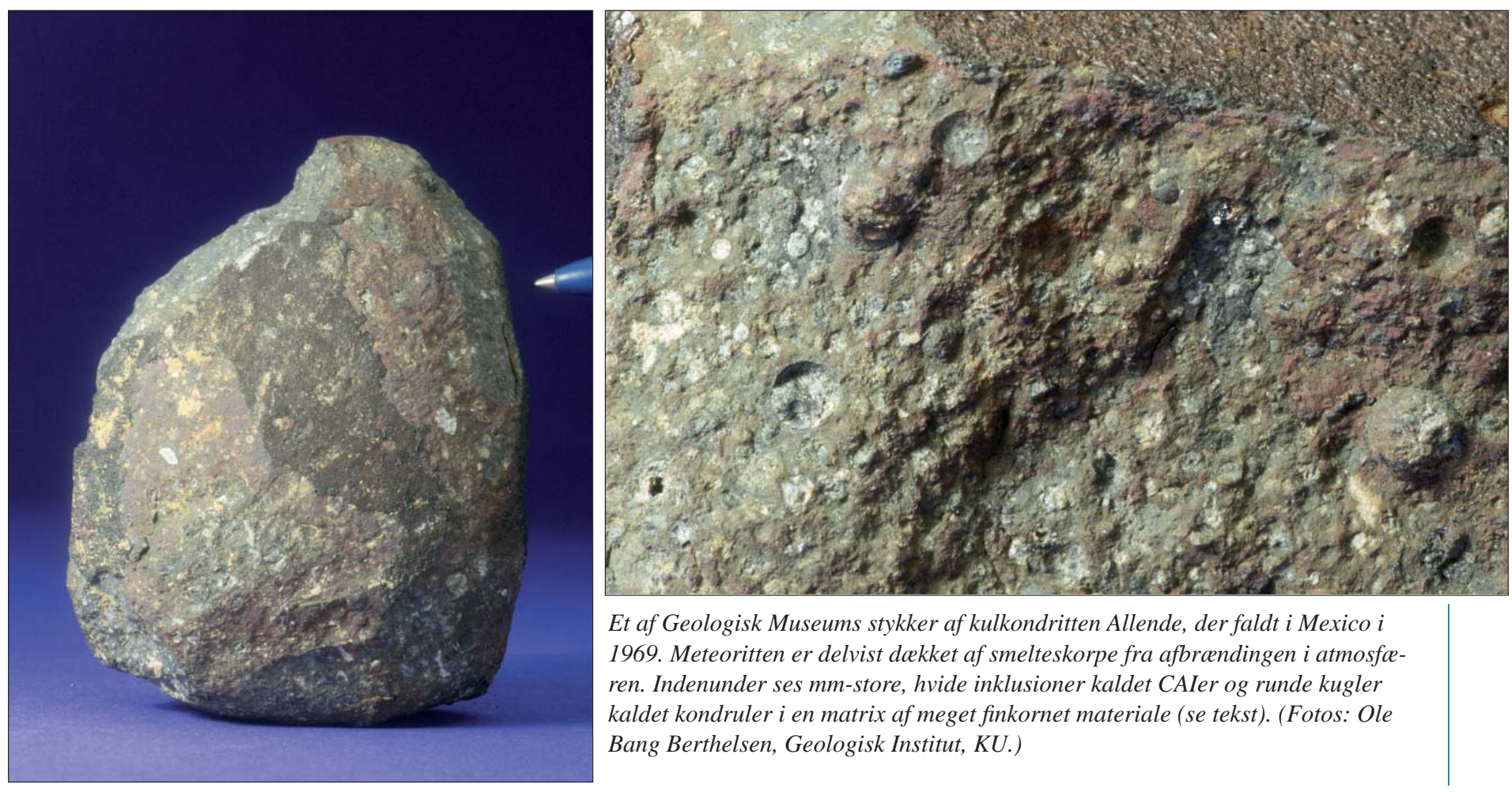

Et af Geologisk Museums stykker af kulkondritten Allende, der faldt i Mexico i 1969. Meteoritten er delvist dcekket af smelteskorpe fra afbrcendingen i atmosferen. Indenunder ses mm-store, hvide inklusioner kaldet CAIer og runde kugler kaldet kondruler i en matrix af meget finkornet materiale (se tekst). (Fotos: Ole Bang Berthelsen, Geologisk Institut, KU.) 
Det ældste materiale fra Solsystemet Kondruler er mm-store runde objekter, der blev helt eller delvist opsmeltet $i$ det unge solsystem og genkrystalliseredes inden for minutter eller timer (figuren øverst på denne side). Kondruler består primært af olivin og pyroxen, silikatmineraler, der også er helt almindelige på Jorden. Sammen med finkornet støv og andre partikler klumpede de sig sammen og blev til det, vi kalder asteroider. Mange af dem er sikkert også endt i planeterne, men det kan vi af gode grunde ikke sige noget sikkert om - bevismaterialet er for længst omsmeltet. Nogen af de kondruler, der endte i en asteroide, er blevet opbevaret stort set uforandrede, indtil den dag de blev slået løs og startede den færd gennem solsystemet, der endte med deres fald på Jorden som en meteorit.

En anden vigtig bestanddel i kondritterne er de inklusioner, der kaldes calcium- aluminium-rige inklusioner eller CAIer. De er dannet ved høje temperaturer på et meget tidligt tidspunkt i Solsystemets udvikling. Vi kender ikke til materiale fra Solsystemet, der er dannet tidligere end CAIerne. De består, som navnet antyder, næsten udelukkende af krystalline silikater og oxider, der er rige på calcium, aluminium og desuden titan. Ikke alle CAIer er dannet ved opsmeltning, og ligesom kondrulerne ser det ud som om, nogle CAIer har været udsat for opvarmning adskillige gange. De fleste CAIer har isotop- og grundstofforhold, der viser, at de eller deres forgængere dannedes ved fordampning og/eller kondensation.

Solsystemets alder bliver på nuværende tidspunkt fastsat efter de nyeste og mest præcise aldre på CAIer, som er på 4,5672 mia. år. Denne alder er fundet i CAIer fra kulkondritten Efremovka.

Selvom disse objekter studeres intenst af forskningsgrupper over hele verdenen, har vi stadig kun vage ideer om, hvor og hvordan de er dannet. En forståelse af de fysiske forhold, de er dannet ud fra, vil være et kvantespring fremad $\mathrm{i}$ vores forståelse af de allertidligste faser i vores solsystems udvikling.

Et vigtigt spor, der kan fortælle os om CAIernes dannelse, er den uddøde aluminium-isotop ${ }^{26} \mathrm{Al} .{ }^{26} \mathrm{Al}$ henfalder til ${ }^{26} \mathrm{Mg}$, med en halveringstid på 730.000 år, så der er ikke noget af det oprindelige ${ }^{26} \mathrm{Al}$ til stede $i$ dag. Størstedelen af CAIerne har et meget højt indhold af datterisotopen ${ }^{26} \mathrm{Mg}$ i forhold til andre Mg-isotoper, og det kan bedst forklares ved, at calcium-aluminium-inklusionerne engang har indeholdt ${ }^{26} \mathrm{Al}$.

Hvis en asteroide blev dannet, mens der stadig var ${ }^{26} \mathrm{Al}$ tilstede, vil henfaldet frigøre tilstrækkelig varme i dens indre til, at opsmelte asteroiden. Tilstedeværelsen af radioaktivt ${ }^{26} \mathrm{Al}$ i det tidlige solsystem kan derfor forklare noget, der indtil for få år siden var et mysterium - hvorfor vi har så mange meteoritter fra små, opsmeltede asteroider. Samtidigt giver ${ }^{26} \mathrm{Al}$ os et redskab til

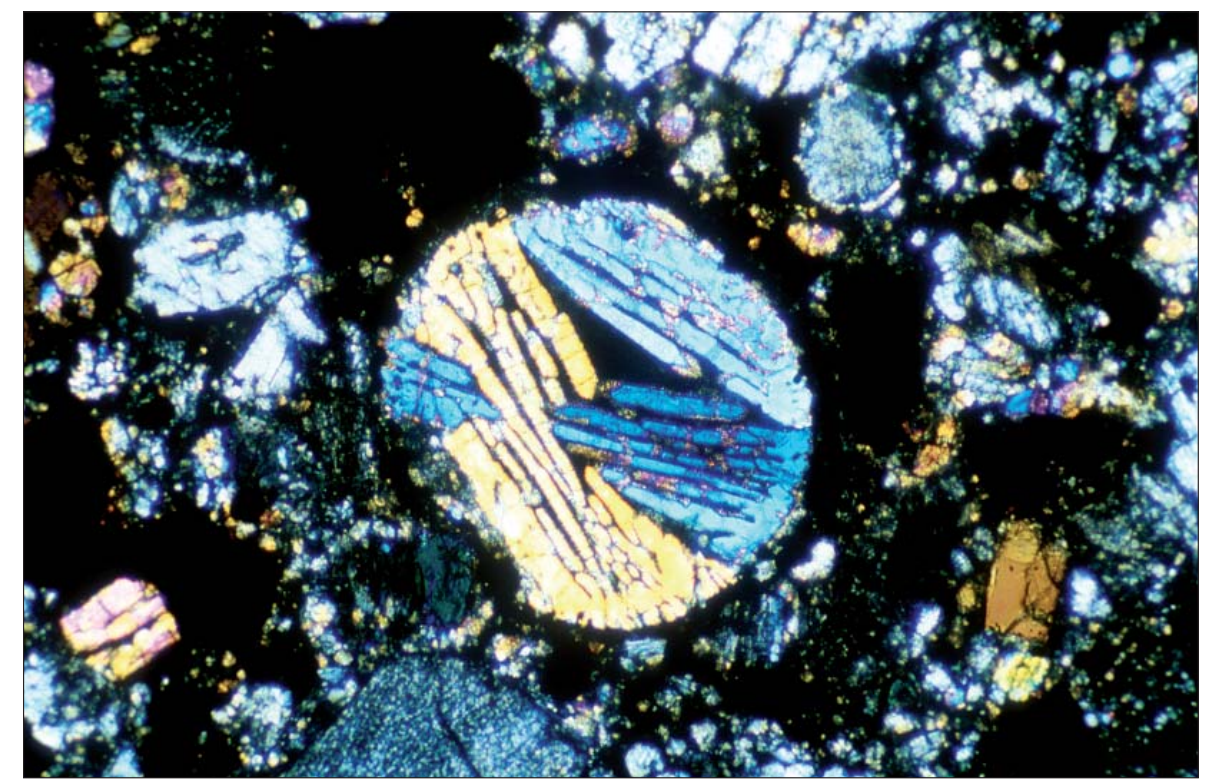

Tyndslib af Allende-meteoritten. Midt i billedet ses en kondrule med en diameter på 0,7 mm. Kondrulen består primert af lameller af mineralet olivin. Den runde form skyldes, at kondrulen er størknet som en smeltedråbe i frit kredsløb om Solen. (Foto: Henning Haack, Geologisk Museum)

at opklare tidsforskellene på begivenheder, der fandt sted i det meget tidlige solsystem. Nye og meget præcise målinger af $\mathrm{Mg}$ isotoperne, som er foretaget ved Geocenter København, viser, at de fleste CAIer i vores solsystem kan være dannet inden for et tidsrum på helt ned til 20.000 år.

Til forskel fra CAIerne har kondrulerne meget varierende overskud af ${ }^{26} \mathrm{Mg}$. Det tyder på, at de dannedes over et længere tidsrum - tilsyneladende er de ældste lige så gamle som CAIerne, mens de yngste først blev dannet omkring 3 mio. år senere. Variationer imellem kondrulerne i de forskellige kondritgrupper og spor efter gentagne cyklusser af processer tyder på, at kondrulerne er dannet ved fænomener, der fandt sted $i$ hele asteroidebæltet. At kondruler er den primære bestanddel i kondritterne, fortæller os, at de er dannet ved en af de vigtigste processer i nebulaen (tågen) $\mathrm{i}$ det tidlige solsystem. Det er derfor meget frustrerende, at vi endnu ikke forstår, hvordan de blev dannet.

\section{Planetlignende asteroider}

Kondritterne viser os, at mange asteroider aldrig blev opvarmet og derfor aldrig fik nogen egentlig geologisk udvikling. De forblev relativt kolde og var derfor det perfekte sted at opbevare primitivt materiale fra solsystemets oprindelse. Mange andre typer meteoritter kommer imidlertid fra asteroider, der har været helt eller delvist opsmeltede. Vi regner med, at de opsmeltede asteroider dannedes højst 1 mio. år efter solsystemets dannelse - mens der stadig var tilstrækkeligt med ${ }^{26} \mathrm{Al}$ til at bringe asteroiden op på smeltepunktet.

Når temperaturen i asteroiden har nået metallets smeltepunkt, vil metallet smelte og løbe ind i centrum af asteroiden og danne kernen. Den samme proces fandt sted på de indre planeter, som fx Jorden. Metallet tager alle de grundstoffer med sig, som er opløselige i smeltet metal. Det er for eksempel guld og platin, hvilket er årsagen til, at disse to grundstoffer er så sjældne på Jordens overflade. Det er altså ikke nødvendigvis de tungeste grundstoffer, der samles i kernen. Tunge grundstoffer som uran, bly og kviksølv er ikke opløselige i metal og bliver derfor i kappen og skorpen på opsmeltede asteroider og planeter.

Hvis en sådan differentieret asteroide (se figuren øverst på næste side) senere bliver involveret $\mathrm{i}$ et katastrofalt kosmisk trafikuheld, vil stumper af asteroidens indre spredes i Solsystemet. Vi har fundet stumper af omkring 100 forskellige opsmeltede asteroider i form af meteoritter. Fra metalkernen har vi jernmeteoritter fra 80-90 forskellige asteroider. Fra grænsen mellem kerne og kappe har vi såkaldte pallasitter fra mindst 3 forskellige asteroider. Besynderligt nok har vi meget få meteoritter fra kappen af asteroider. Vi ville forvente, at der skulle være et betydeligt volumen rigt på mineralet olivin - men sådanne meteoritter er aldrig blevet fundet. Vi har dog nogle meteoritter fra den øvre del af kappen fra nogle enkelte asteroider. Fra den vulkanske skorpe af de opsmeltede asteroider har vi basaltiske meteoritter.

Ved at bestemme spektrene af det sollys, der reflekteres fra en asteroides overflade, er det desuden muligt at finde ud af, hvilke mineraler der findes på dens overflade. På den måde kan vi se, at asteroiderne ligesom meteoritter er opdelt i mange forskellige typer. Der findes primitive kondritlignenede asteroider, en enkelt asteroide med en intakt 


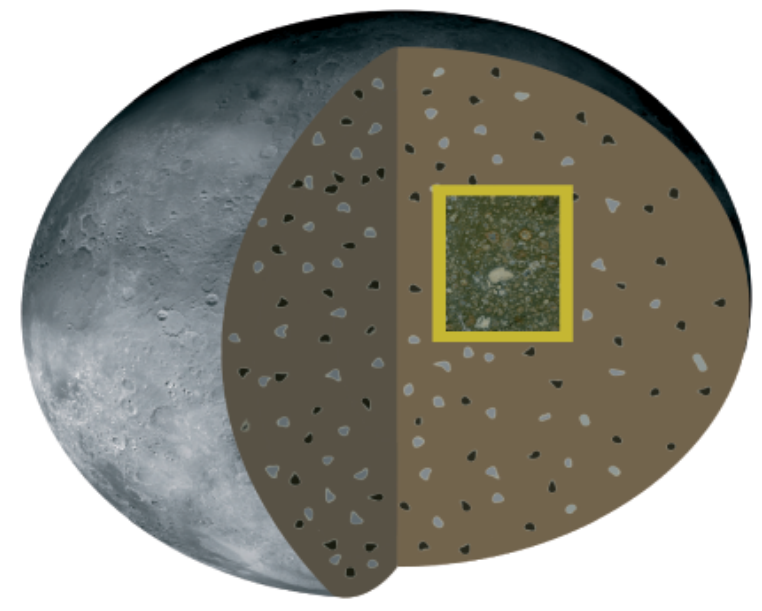

Tværsnit gennem en primitiv asteroide, hvor støv, kondruler og metalkorn er bevaret næsten uforandret siden solsystemets oprindelse for ca. 4,6 mia. år siden. Kondritter er fragmenter af sådanne asteroider.

Kondrit fra en primitiv asteroide

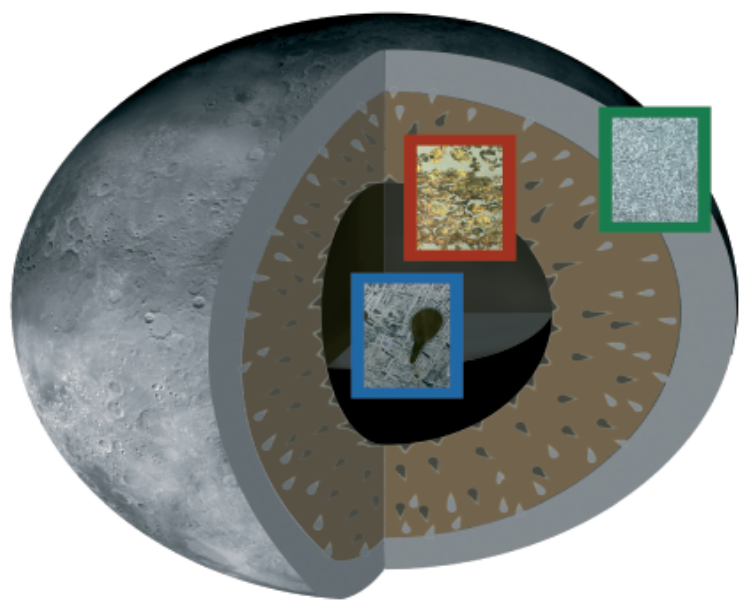

Tværsnit gennem en magmatisk eller differentieret asteroide. Disse asteroider opsmeltedes inden for få millioner år efter solsystemets oprindelse og blev derved opdelt i en metalkerne, en silikatkappe og en skorpe.

Pallasit fra kerne-kappe grænsen

Jernmeteorit fra kernen

(Grafik: Anne Haastrup Hansen, Statens Naturhistoriske Museum)

vulkansk overflade og mange asteroider, der tilsyneladende er fragmenter af kerner, kapper og skorper fra tidligere tiders opsmeltede asteroider.

De primitive, uopsmeltede asteroider findes hovedsageligt i de ydre dele af asteroidebæltet, mens de opsmeltede primært findes i de indre dele.

\section{En enestående basaltisk meteorit}

Det er ikke kun på Jorden, der findes vulkaner. Selv på asteroiderne har der engang været omfattende vulkansk aktivitet. Stumper af disse vulkaner drysser fra tid til anden ned på Jorden i form af basaltiske meteoritter. I 1999 opdagede et hold af franske meteoritjægere i Sahara en ny basaltisk meteorit - nu kendt som SAH99555 (foto nederst på denne side). Denne enestående meteorit tilhører en sjælden gruppe af meteoritter, der kaldes angritter - opkaldt efter meteoritten Angra dos Reis, som faldt i Brasilien i 1869. Angritter har en meget ens sammensætning af iltisotoper og kommer fra en asteroide, hvor stort set alle flygtige elementer var afgasset. SAH99555 er en finkornet bjergart, der primært består af aluminium- og titaniumrig pyroxen, calciumrig olivin og anorthit.

Da SAH99555-meteoritten er frisk og uforvitret, forsøgte et hold forskere fra Geocenter København at datere meteoritten med to forskellige metoder. Den første er baseret på henfaldet af ${ }^{238} \mathrm{U}$ og ${ }^{235} \mathrm{U}$ til hhv. ${ }^{206} \mathrm{~Pb}$ og
${ }^{207} \mathrm{~Pb}$. Dette system giver en såkaldt absolut bly-bly-alder for både mineraler, bjergarter og meteoritter. Resultatet af analyserne gav overraskende en alder på 4,566 mia. år - åbenbart kun en million år yngre end CAIerne! Dermed er SAH99555 den ældste kendte vulkanske bjergart i Solsystemet. På det tidspunkt burde der stadig have været
${ }^{26} \mathrm{Al}$ tilstede i meteoritten, og forskerne fortsatte derfor med at søge efter spor af ${ }^{26} \mathrm{Al}$ i form af et overskud af ${ }^{26} \mathrm{Mg}$ ligesom for CAIer og kondruler.

Forskerne fandt, at alle angritterne indeholder små mængder af overskydende ${ }^{26} \mathrm{Mg}$, i forhold til andet materiale fra objekter i det indre solsystem, inklusive Jorden, Månen,
Skive af den basaltiske meteorit SAH99555, der kan ses udstillet på Statens Naturhistoriske Museum. Skiven måler $12 \mathrm{~cm}$ på den lange led. De runde huller er gasbobler. (Foto: Luc Labenne)

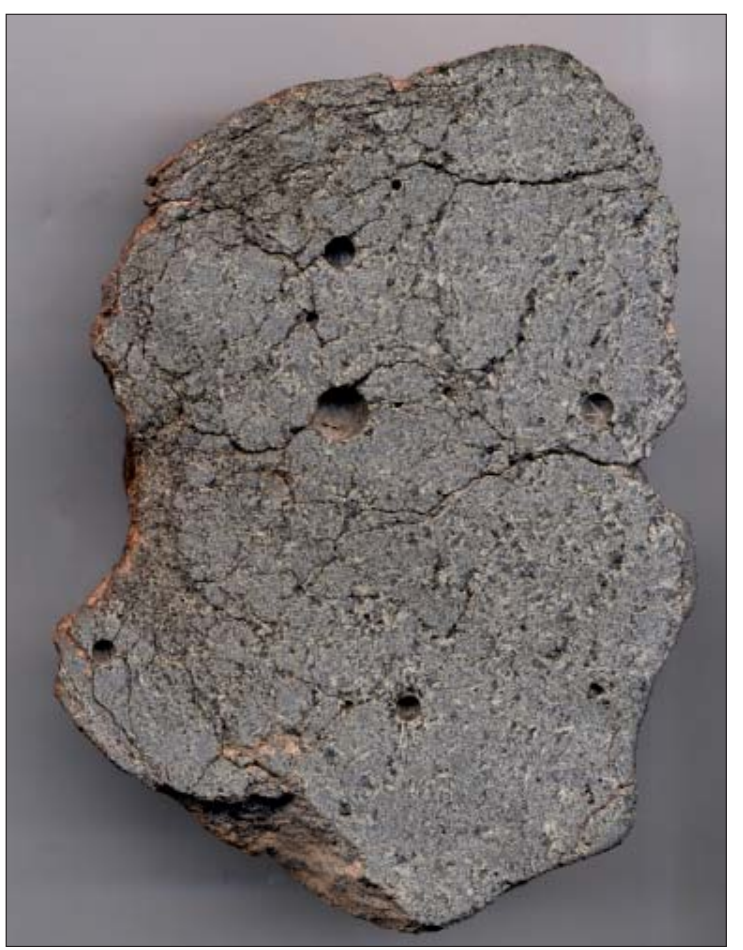




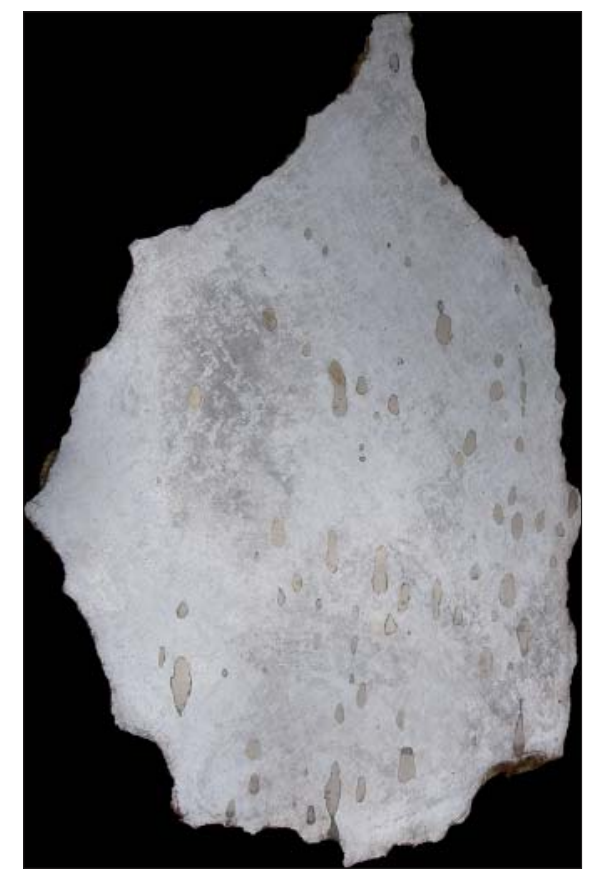

Skive af Agpalilik-meteoritten, der er udstillet på Statens Naturhistoriske Museum. Skiven er $185 \mathrm{~cm}$ høj og vejer over en halv ton-det er verdens største meteoritskive. Skiven er poleret og cetset, så man kan se, at den består af en sammenhæengende krystalstruktur. (Foto: Jacob Lautrup, GEUS)

Mars og kondritterne. Det overskydende ${ }^{26} \mathrm{Mg}$ kan benyttes til at beregne aldre for den vulkanske aktivitet på angritternes moderlegeme, og det viser sig, at den vulkanske aktivitet er ca. 3 mio. år yngre end dannelsen af CAIerne, som er solsystemets ældste objekter. Ved at kombinere denne aldersforskel med den absolutte bly-bly-alder for SAH99555 er det muligt at beregne en ny alder for calcium-aluminium-inklusionerne på ca. 4,5695 mia. år. Denne CAI-

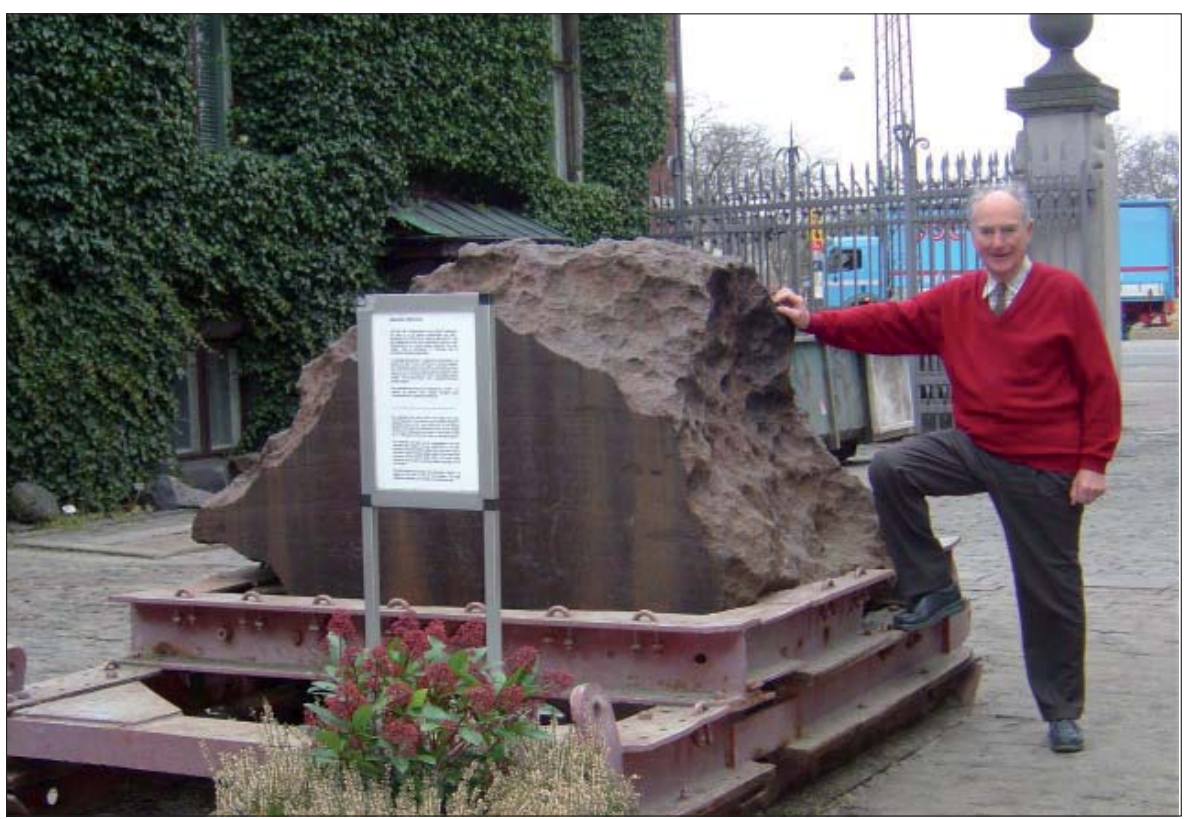

Vagn Buchwald ved Agpalilik-meteoritten i Geologisk Museums gård, marts 2006. Man kan se, hvor den store skive i udstillingen er skåret ud af meteoritten. (Foto: Anne H. Hansen, GM) alder er ca. 2 mio. år ældre end de tidligere bud og viser, at solsystemet nok er ældre end tidligere antaget.

\section{Jernmeteoritter}

Jernmeteoritter ligner ikke noget andet, vi kan finde på Jordens overflade. Hvis man er så heldig at finde en jernmeteorit, vil man straks kunne mærke, at den er omtrent dobbelt så tung som en almindelig sten af samme størrelse. Jernmeteoritter er små stumper af asteroiders planetkerner. Dybt nede i Jorden findes der tilsvarende materiale, men vi vil aldrig nogensinde kunne få hentet en prøve op. Jernmeteoritter er derfor planetkerner ser ud. vores eneste mulighed for at se, hvordan

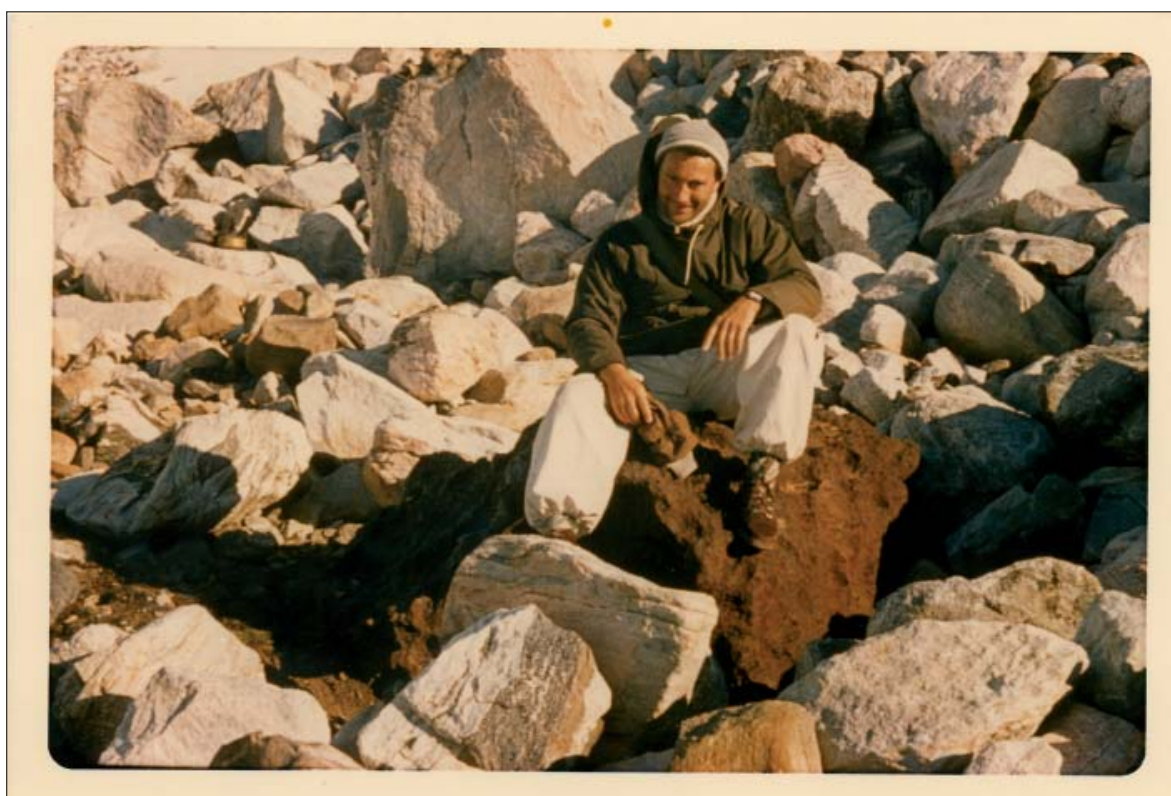

Vagn Buchwald siddende på Agpalilik d. 3. august 1963 - kort efter han havde fundet meteoritten. (Foto: Vagn Buchwald)
Jernmeteoritter er ikke bare dobbelt så tunge som almindelige sten - de er også ofte smukt formede efter den voldsomme tur ned gennem Jordens atmosfære. Hvis man skærer dem over, vil man kunne se, at de indeni ofte består af en enkelt forgrenet krystal. Selv den store Agpalilikskive i på Geologisk Museum er et fragment af en stor forgrenet enkeltkrystal (foto øverst til vestre). Asteroidernes kerner størknede ganske langsomt, og der har derfor formentlig været tid til at krystallerne kunne vokse sig kilometerstore. Ved at studere krystallerne kan man faktisk måle, hvor hurtigt asteroidekernen køledes af. Kølehastighederne er nogle få grader per million år - hvilket tyder på, at asteroiderne havde diametre på knap $100 \mathrm{~km}$.

\section{Hvor kommer jernmeteoritterne fra?} Hvis man analyserer jernmeteoritternes kemiske sammensætning, kan man se, at mange af dem ligner hinanden. Det gør de faktisk også rent bogstaveligt, da de jernmeteoritter, der har nogenlunde samme kemiske sammensætning, sædvanligvis også viser sig at have samme type krystalstruktur og indeholde de samme mineraler. Det tyder på, at de jernmeteoritter, der er kemisk og strukturelt sammenlignelige, også kommer fra den samme asteroidekerne. På den måde inddeler man jernmeteoritterne i grupper med hver deres betegnelse og formentlig fælles oprindelse i den samme asteroidekerne. Den største gruppe af jernmeteoritter kaldes IIIAB og indeholder knap 300 kendte meteoritter, deriblandt Cape York-meteoritterne.

Det er dog langtfra alle jernmeteoritter, der falder i disse grupper. Dem, der ikke passer ind i grupperne, kalder vi unikke eller ugrupperede. De unikke jernmeteoritter kommer formentlig fra asteroider, hvorfra 
vi endnu ikke har fundet andre meteoritter. Ved at tælle antallet af jernmeteoritgrupper og unikke jernmeteoritter har vi således fundet ud af, at vi har knap 1.000 kendte jernmeteoritter, som kommer fra knap 100 asteroider.

\section{Fundet af Agpalilik}

I Geologisk Museums gård står et brudstykke af jernmeteoritten Cape York (figuren øverst til højre på foregående side). Stykket, som før skæring vejede 20,1 tons, hedder Agpalilik efter sit findested i Melville Bugten, Nordvestgrønland. Agpalilik er fundet af Vagn Buchwald, der er emeritus professor ved Geologisk Museum. Vagn Buchwald er metallurg og tidligere lektor ved DTU.

Med støtte fra Grønlandsministeriet fik Vagn Buchwald i somrene 1961 og 1963 stillingen som videnskabelig forbindelsesofficer på Thule Air Base. I sin fritid afsøgte han systematisk de isfri områder. I sommeren 1963 afsøgtes en ret utilgængelig halvø, Agpalilik, der end ikke fandtes på kortet. Her fandt Vagn Buchwald d. 31. juli Agpalilik (figuren nederst på foregående side).

Den lå næsten dækket af store gnejsblokke. Formentlig fandt faldet sted for mere end 2.000 år siden, da området var dækket af svær is. Meteoritten må have lavet et krater $\mathrm{i}$ isen, og da isen senere smeltede, blev jernblokken blot aflejret blandt de andre stenblokke. Meteoritten var ukendt af de lokale grønlændere, og da han fortalte om fundet var de yderst skeptiske.

Polering og ætsning med fortyndet salpetersyre har frembragt den karakteristiske Widmanstätten-struktur, "Himlens eget varemærke". Strukturen er umulig at eftergøre, da det kan beregnes, at den må være dannet under langsom afkøling fra høj temperatur. Agpalilik var ved $1.000^{\circ} \mathrm{C}$ en kæmpe-eenkrystal på $2 \mathrm{~m}$, den største eenkrystal af metal, der kendes. På snitfladerne ses parallelle inklusioner af det umagnetiske jernsulfid troilit, FeS, der markerer op-ned retningen på den lille asteroide, hvoraf Agpalilik og

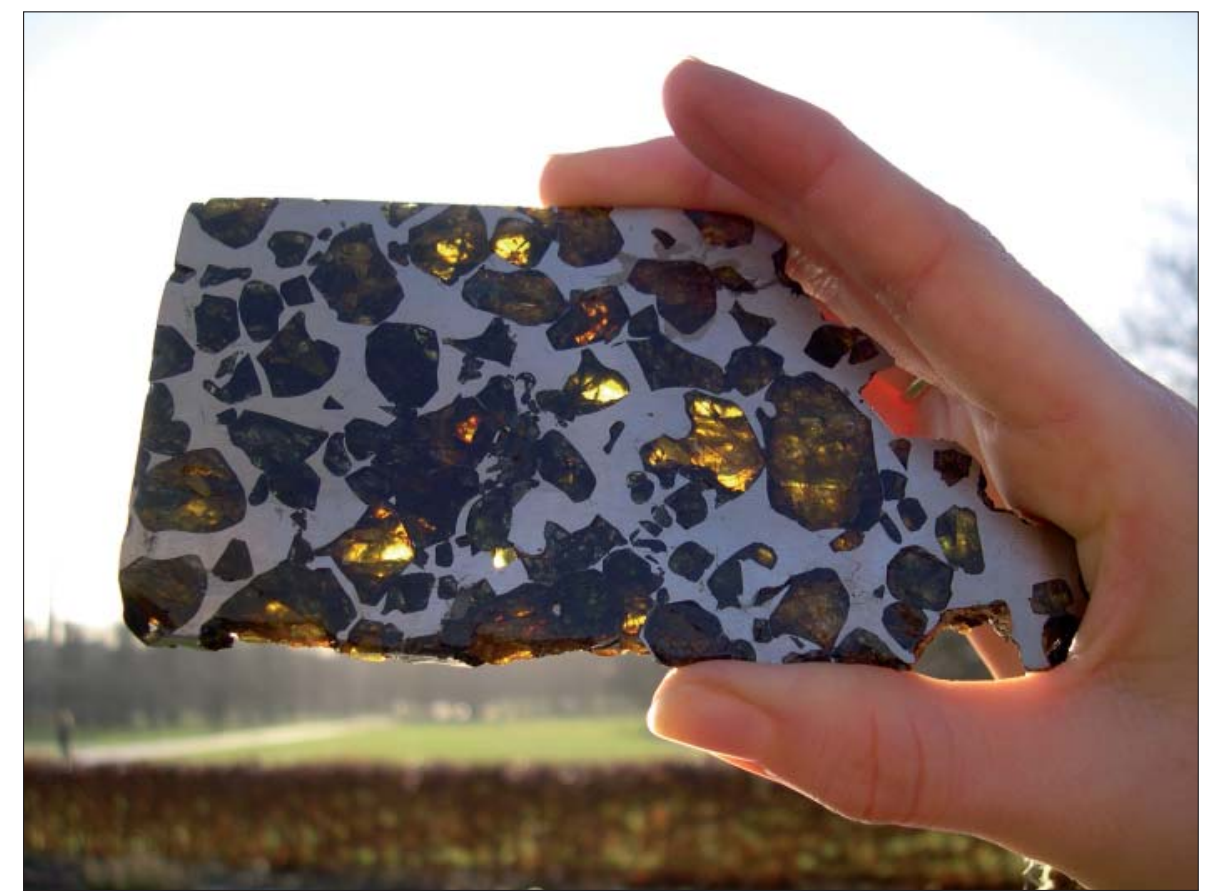

Skive af pallasitten Esquel. (Foto: Henning Haack)

Cape York oprindelig var en del. Cape York meteoritbygen er med sin udstrækning på over $100 \mathrm{~km}$ og sine indtil nu kendte tolv større stykker, i alt 58 tons, verdens største.

\section{Pallasitter}

Pallasitter er nogle af de lettest genkendelige og smukkeste meteoritter. De består af nogenlunde lige del metal og silikat - det sidste i form af mineralet olivin. Hvis man holder en tynd skive pallasit op mod lyset, vil man kunne se lyset skinne gennem de $\mathrm{cm}$-store olivinkrystaller (foto ovenfor).

Blandingen af metal og olivin giver os en god idé om, hvor disse pallasitter kommer fra. Olivin er et almindeligt silikatmineral, som formentlig dominerede den nedre kappe $i$ asteroider, ligesom metal dominerede kernen. Det er derfor svært at forestille sig andet, end at pallasitterne kommer fra

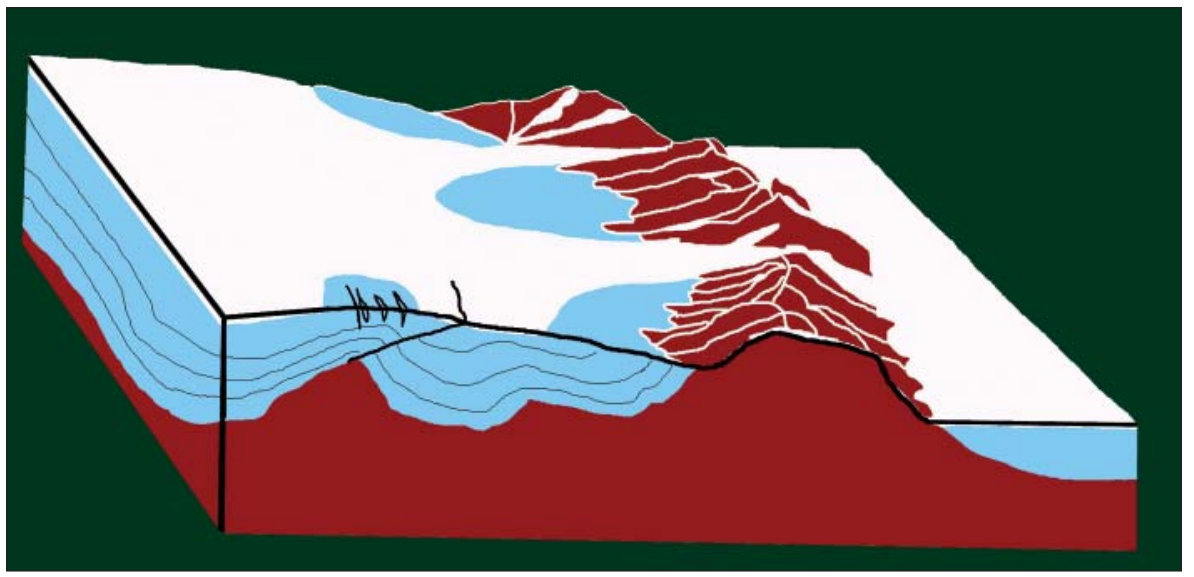

Tvarsnit af de Transantarktiske Bjerge. Den is, der strander på forkanten (dvs. til venstre) af bjergene, fordamper således, at dens indhold af meteoritter blotlcegges. (Grafik: Ralph Harvey/Henning Haack) grænselaget mellem kerne og kappe i en differentieret asteroide.

\section{Meteoritjagt}

Der ligger mange meteoritter i den danske natur, som bare venter på at blive fundet. De fire meteoritter, der er fundet i den sydlige del af Danmark, er enten fundet, fordi nogen har set dem falde (Mern og Aarhus), eller fordi de er dukket op, når man har gravet $\mathrm{i}$ jorden (Jerslev og Feldsted). Så selvom vi regner med, at der falder ca. tre meteoritter om året i Danmark, er der ikke mange chancer for at finde nogen af dem. Vi håber dog 
stadig, at du vil se godt efter, når du færdes i naturen - hvis vi alle gjorde det, ville vi kunne finde mange meteoritter.

Meteoritter falder næsten jævnt fordelt over hele kloden - men det er ikke alle steder, det er lige let at finde dem. De meteoritter, der falder i oceanerne, ser vi næppe igen, og de, der falder i områder med tæt vegetation, har heller ikke mange chancer for at blive fundet.

Det allerbedste sted at finde meteoritter er imidlertid så langt fra civilisationen, som man kan komme - Antarktis. Her er der ingen vegetation til at skjule meteoritterne, og naturen hjælper os ligefrem med at samle meteoritterne sammen.

\section{Meteoritjagt på Antarktis}

Antarktis har vist sig at være det bedste sted på kloden at finde meteoritter. Der er fundet omkring 30.000 meteoritter på Antarktis.

Hver sæson sendes der en amerikansk ekspedition afsted med frivillige meteoritforskere for at finde meteoritter på Antarktis. De bringer typisk mellem 500-1.000 meteoritter tilbage efter 5-6 ugers feltarbejde på isen. Japan, Kina og Europa har også sendt meteoritjægere til Antarktis.

Der er flere grunde til, at der kan findes mange meteoritter på Antarktis. Først og fremmest er Antarktis et meget stort kontinent. Der falder derfor mange meteoritter på

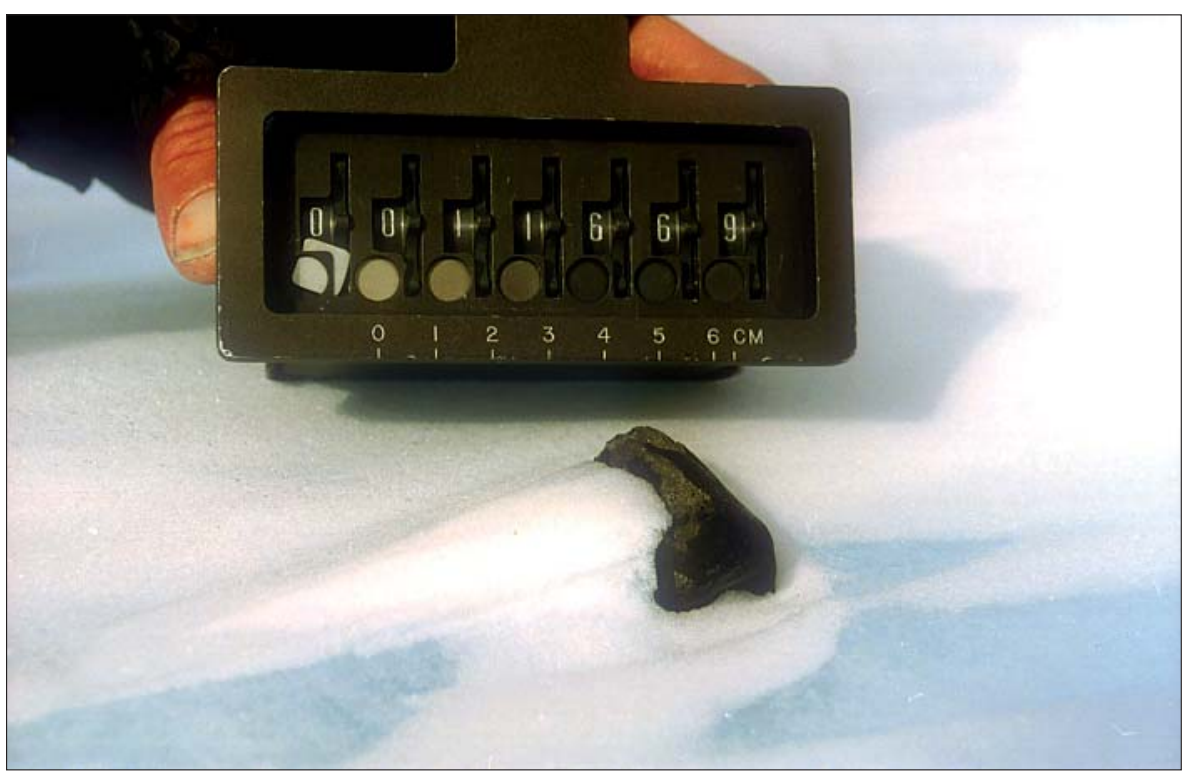

Hvert nyt meteoritfund i Antarktis fotograferes og tildeles et ID-nummer. Nummerviseren er den samme model, der brugtes af Apollo-astronauterne på Månen. (Foto Ralph Harvey)

Antarktis. Når meteoritterne er faldet, bliver de dækket med sne og glider langsomt ud mod kysterne. På sin vej mod kysten skal meget af isen igennem De Transantarktiske Bjerge. Det meste af isen glider ind gennem bjergkæden i nogle af Jordens største gletschere, men noget af isen strander på forsiden af bjergene. En kold og knasende tør, såkaldt katabatisk vind fra det centrale Antarktis, sørger så for at feje den strandede is ren for sne, så isen blotlægges (figuren nederst på den foregående side).

Isen har en flot blå farve, og man kalder derfor isfelterne for blåisområder. Fordi luften er så tør, og vinden blæser uophørligt, fordamper isen også. Selvom det aldrig er tøvejr, så forsvinder der ca. $20 \mathrm{~cm}$ is om året. Da meteoritterne ikke fordamper, ligger de tilbage på overfladen af isen, efterhånden som den fordamper (figuren ovenfor til højre).

En anden stor fordel ved at søge efter meteoritter på Antarktis er, at det er meget let at få øje på en sort meteorit på en blank isoverflade. Små meteoritter kan let ses på 50-100 m afstand, og det er derfor muligt at afsøge meget store områder fra en snescooter. Endelig er Antarktis også et godt sted at opbevare meteoritter - de, der findes i dag, har typisk ligget $i$ isen i 100.000 år - og ligner stadig friskfaldne meteoritter. Selvom mange af de meteoritter, der findes, er af samme type som tidligere fund, findes der hvert år nye unikke meteoritter, der lærer os nyt om vores Solsystems oprindelse.

\section{Info}

Hvis du vil vide mere om emnet, kan du besøge Geologisk Museums nye permanente udstilling: "Solsystemet - fra altings oprindelse til Livets opståen". Du kan også læse mere om emnet i kataloget til udstillingen, der både kan købes på museet eller hentes fra www.geologiskmuseum.dk 